\title{
Usefulness of a Nested-Polymerase Chain Reaction for Molecular Diagnosis of Human T-cell Lymphotropic Virus Type I/II
}

\author{
Sandra Gallego/ ${ }^{+}$, Andrea Mangano*, René Gastaldello, Luisa Sen*, Silvia Medeot
}

\author{
Laboratorio de Virus Linfotrópicos Humanos, Instituto de Virología “Dr. José María Vanella”, Facultad de Ciencias Médicas, \\ Universidad Nacional de Córdoba, Enfermera Gordillo s/n, Ciudad Universitaria, Córdoba, Argentina *Laboratorio de Biología \\ Celular y Retrovirus, Hospital Nacional de Pediatría “J. P. Garrahan”, Buenos Aires, Argentina
}

This study aimed at implementing a Nested-polymerase chain reaction (Nested-PCR) for the molecular diagnosis of human T-cell lymphotropic virus type I/II (HTLV-I and HTLV-II) infections in peripheral blood mononuclear cells of infected subjects in Argentina. The sensitivity and specificity of the assay for the detection of regional strains were assessed by comparing them with the molecular assay of reference PCR-hybridization. The Nested-PCR detected 1 MT-2 cell ( $\geq 8$ proviral copies)/1x106 non-infected cells showing high sensitivity for provirus detection. While both molecular assays showed high specificity (100\%) for HTLV-I and HTLV-II detection, the sensitivity values differed: 100\% for Nested-PCR and 67\% for PCR-hybridization assay. Moreover, this technique showed less sensitivity for the detection of DNA sequences of HTLV-II (33\%) than for the detection of DNA sequences of HTLV-I (75\%).

The high sensitivity and specificity of the Nested-PCR for regional strains and its low costs indicate that this assay could replace the PCR-hybridization assay for the molecular diagnosis of HTLV-I/II infections. It will be interesting to assess the usefulness of this assay as a tool for the molecular diagnosis of HTLV-I/II infections in other developing countries. Other studies that include a greater number of samples should be conducted.

Key words: human T-cell lymphotropic virus type I/II - nested-polymerase chain reaction - Argentina

The human T-cell lymphotropic virus type I (HTLV-I) is the etiologic agent of adult T-cell leukaemia and tropical spastic paraparesis (TSP) (Uchyama et al. 1977, Osame et al. 1986, Höllsberg \& Hafter 1993). Other diseases such as chronic inflammatory arthropathy, polymyositis, uveitis, alveolitis, and infective dermatitis have been described in patients infected with HTLV-I (Jacobson 1996).

The HTLV-II has been isolated from patients with hairy T-cell leukaemia (Kalyanaraman et al. 1982); however, its etiologic role as an oncogenic agent has not been confirmed yet.

The diagnosis of these retroviruses infection is based on the initial specific antibody detection by particle agglutination assay (PA) or enzyme immunoassays (EIA) and subsequent confirmation by Western blot $(\mathrm{Wb})$ or indirect immunofluorescence assay (IFA). Due to the HTLV-I and HTLV-II (Cann \& Chen 1990) high amino acid sequence homology, there may be cross-reactivity when using serological assays. Therefore, molecular assays are a useful means to differentiate between the two viruses. Furthermore, the retroviral infection can not be discarded nor confirmed in a high percentage of subjects showing reactive screening and indeterminate results by $\mathrm{Wb}$ (Lipka et al. 1991, Zaaijer et al. 1994, Gastaldello et al. 2001, Thorstensson et al. 2002). Molecular assays are then useful to the diagnosis of infection in these subjects with persistently indeterminate patterns.

\footnotetext{
${ }^{+}$Corresponding author. Fax: $+54-351-433.4265$. E-mail: sgallego@cmefcm.uncor.edu.

Received 3 November 2003

Accepted 26 May 2004
}

The first "gold standard" molecular assays used for the detection and typing of HTLV-I/II infections were the polymerase chain reaction (PCR) that involved the hybridization of the amplification products with DNA probes marked with radioactive $\mathrm{P}^{32}$ (Barun \& Srinivasan 1989). It has been reported that not all specimens are found positive when examined by a single PCR due to the low level of infected lymphocytes in HTLV-I-infected individuals. Therefore, it is necessary to perform a second amplification (Nested-PCR) in order to improve the sensitivity of the assay (Matsumoto et al. 1990, Tuke et al. 1992, Vallejo \& García-Sáiz 1995, Vandamme et al. 1997, Silva et al. 2002).

The purpose of this study was to implement and adapt a simple Nested-PCR protocol (Tuke et al. 1992) as well as to assess its sensitivity for the detection of HTLV-I/II strains circulating in Argentina in comparison with liquid PCR-hybridization as a reference assay.

\section{MATERIALS AND METHODS}

\section{Nested-PCR assay}

Source and isolation of DNA - The following cell lines have been used as a source of DNA: (i) MT-2, human Tlymphotropic virus type-1 (HTLV-1)-infected cell line (Miyoshi et al. 1981) was supplied by Dr Horacio Salomón from the National Reference Center for AIDS Argentina. Each cell carries 8 copies of the HTLV-I provirus; (ii) HT, uninfected cell line was used as a negative control and was kindly provided by Dr Renu B Lal (CDC, Atlanta, US).

To validate the sensitivity of the assay different proviral DNA concentrations were used and serial dilutions of the MT- 2 cells were carried out from $2 \times 10^{6}, 1 \times 10^{5}, 1 \times 10^{4}, 1$ $\times 10^{3}, 1 \times 10^{2}, 10$ up to 1 cell. In each tube, DNA carrier was balanced with T- cells up to a concentration of $1 \times 10^{6}$.

DNA was obtained digesting with proteinase $\mathrm{K}$. The pellets were suspended in $100 \mu \mathrm{l}$ of lysis buffer composed 
of $5 \mathrm{mMTRIS} \mathrm{ClH}, 0.5 \%$ Tween $20,0.5 \%$ Triton y $80 \mu \mathrm{g} / \mathrm{ml}$ of proteinase K (Fungal $100 \mathrm{mg}$, Gibco). The cells were digested with proteinase $\mathrm{K}$ for $1 \mathrm{~h}$ at $60^{\circ} \mathrm{C}$, and then, the enzyme was inactivated for $10 \mathrm{~min}$ at $95^{\circ} \mathrm{C}$. The lysates were stored at $-20^{\circ} \mathrm{C}$ until they were used.

A $\beta$-actin PCR was done to control the quality of the extracted DNA in all the samples (Peng et al. 1993).

Nested-PCR procedure - We adopted the protocol previously described by (Tuke et al. 1992) and made some modifications. PCR was performed in a two-step reaction, first, with a pair of outer primers N1 (5'-CGGATACCC AGTCTACGTGT-3') N2 (5'-GAGCCGATAACGCGT CCATC-3') and then with a pair of inner primers N3 (5'GTGTTTGGCGATTGTGTACA-3') N4 (5'-CCATCGA TGGGGTCCCA-3'). All four primers used hybridize with a sequence of the tax/rex gene preserved and shared by HTLV-I and HTLV-II.

The reaction mixtures basically contained $1.5 \mathrm{mM}$ $\mathrm{MgCl}_{2}, 0.2 \mathrm{mM}$ of each dNTP, 1 unit of Taq DNA polymerase (Gibco), Buffer Taq 1x (Gibco). Round 1 of the PCR was performed in a total volume of $50 \mu \mathrm{l}$ with $15 \mathrm{ng}$ of each outer primer and $25 \mu 1$ of the cell lysate. After an initial 7 min denaturation at $95^{\circ} \mathrm{C}, 35$ cycles of $95^{\circ} \mathrm{C} 1 \mathrm{~min}, 55^{\circ} \mathrm{C} 1$ $\min , 72^{\circ} \mathrm{C} 1 \mathrm{~min}$ were performed in a Thermal Cycler (Uno II Biometra). Round 2 of the PCR was carried out in a total volume of $49 \mu 1$ of the same reaction mixture with $62.5 \mathrm{ng}$ of each inner primer and $1 \mu \mathrm{l}$ of the first-amplification product. The reaction was carried out using the same temperature and duration as for the first round but, in this case, 25 cycles were performed.

A volume of $20 \mu \mathrm{l}$ of the Nested-PCR amplification product was analyzed by electrophoresis on a $2 \%$ agarose gel stained with ethidium bromide. The samples showing the band of the predicted size (128 bp) were considered positive for HTLV-I/II tax/rex sequence.

Afterwards, an analysis with the restriction enzymes Sau 3A and Taq I was carried out in order to differentiate HTLV-I from HTLV-II. $5 \mu \mathrm{l}$ of the Nested-PCR product were digested in a $20 \mu 1$ reaction mixture composed of 10 units of the restriction enzyme and $1 \mathrm{x}$ enzyme buffer. The reaction with enzyme Sau $3 \mathrm{~A}$ was carried out at $37^{\circ} \mathrm{C}$ for $90 \mathrm{~min}$ and the reaction with enzyme $T a q \mathrm{I}$ was carried out at $65^{\circ} \mathrm{C}$ for $90 \mathrm{~min}$.

A $10 \mu \mathrm{l}$ aliquot of the digestion product was analyzed by electrophoresis on a $4 \%$ agarose gel stained with ethidium bromide. As a result of the digestion of the 128 bp tax/rex gene sequence with enzyme Taq I, there were obtained fragments of $69 \mathrm{bp}, 53 \mathrm{bp}$, and $6 \mathrm{bp}$ for HTLV-II and fragments of $122 \mathrm{bp}$ and $6 \mathrm{bp}$ for HTLV-I. As a result of the digestion of the $128 \mathrm{bp}$ tax/rex gene sequence with enzyme Sau 3A, there were obtained fragments of $104 \mathrm{bp}$ and 24 bp for HTLV-I, while the enzyme did not cut the sequence of $128 \mathrm{bp}$ for HTLV-II.

Liquid PCR-hybridization assay - The PCR reaction was performed in a total volume of $50 \mu 1$ in a reaction mixture composed of $2.5 \mathrm{mM} \mathrm{MgCl}_{2}, 0.4 \mathrm{mM}$ of each dNTP (Promega), 1 unit of Taq DNA polymerase (Promega), 0.2 $\mu \mathrm{M}$ of each primer SK110 (5'-CCCTACAATCCC ACCAGCTCAG-3') and SK111 (5'-GTGGTGGATTTGCC ATCGGGTTTT-3') (Kowok et al. 1988), buffer Taq 1x and $20 \mu 1$ of the cell lysate. The reaction consisted in an initial denaturation at $94^{\circ} \mathrm{C}$ for $10 \mathrm{~s}, 30$ cycles of $94^{\circ} \mathrm{C}$ for $30 \mathrm{~s}$, $53^{\circ} \mathrm{C}$ for $1 \mathrm{~min}$, and $72^{\circ} \mathrm{C}$ for $1 \mathrm{~min}$, followed by a final extension at $72^{\circ} \mathrm{C}$ for $10 \mathrm{~min}$ in a Thermal Cycler (Perkin Elmer Cetus).

The PCR allows the amplification of a $185 \mathrm{bp}$ fragment of a pol gene region conserved and shared by HTLV-I and HTLV-II.

Amplified DNA fragments were analyzed by liquid hybridization with ${ }^{32} \mathrm{P}$ end-labeled probes SK 112 (5'GTACTTTACTGACAAACCCGACCTAC-3') for HTLV-I and SK 188 (5'-TCATGAACCCCAGTGGTAA-3') for HTLV-II (Kowok et al. 1988). Briefly, we hybridized $20 \mu 1$ of the PCR product with a respective probe $(100,000 \mathrm{cpm} /$ reaction) in a total volume of $40 \mu \mathrm{l}$ in $150 \mathrm{mM} \mathrm{ClNa}$ for 5 $\min$ at $96^{\circ} \mathrm{C}$ and for $15 \mathrm{~min}$ at $56^{\circ} \mathrm{C}$. The products were electrophoresed on $5 \%$ polyacrylamide gels at $250 \mathrm{~V}$ for 1 h. Gels were autoradiographed (Kodak AR5-X-OMAT) at $-85^{\circ} \mathrm{C}$ for $24 \mathrm{~h}$.

Sensitivity of the Nested-PCR assay for viral strains circulating in Argentina - Blood samples were obtained from blood donors from the Blood Bank of Hospital Garrahan, Buenos Aires, Argentina and from the Blood Bank of the Universidad Nacional de Córdoba, Argentina: (i) 12 HTLV-I infected subjects, (ii) 3 HTLV-II infected subjects, (iii) 9 subjects with reactive serology for HTLV$\mathrm{I} / \mathrm{II}$ and indeterminate $\mathrm{Wb}$, and (iv) 12 subjects with negative screening for HTLV-I/II.

The diagnosis of infection in the blood samples was corroborated by the detection of specific antibodies for HTLV-I/II through PA (Serodia, Fujirebio, Tokyo, Japan) and its subsequent confirmation by $\mathrm{Wb}$ (Genelabs Diagnostics 2.4) and IFA (Gallego et al. 1997).

Twenty ml of blood with EDTA $\mathrm{K}_{3}$ were obtained from each subject. The blood was diluted in $20 \mathrm{ml}$ of phosphate-buffered saline (PBS) and centrifuged in a FicollHypaque gradient (Pharmacia) in order to obtain the peripheral blood mononuclear cells (PBMCs). After three washes in phosphate-buffered saline, the buffer was removed and the cells were conserved as dry pellets in aliquots of $2 \times 10^{6}$ at $-20^{\circ} \mathrm{C}$. Afterwards, DNA was obtained by lysis with proteinase $\mathrm{K}$, as described previously.

In all samples the amplification of the $128 \mathrm{bp}$ fragment of HTLV-I/II tax/rex gene was performed by the NestedPCR assay previously described. By contrast, the amplification of a $185 \mathrm{bp}$ fragment of the pol gene was performed through the liquid PCR-hybridization assay (taken as a reference assay).

\section{RESULTS}

The Nested-PCR assay implemented detected 1 infected cell $/ 1 \times 10^{6}$ total non-infected cells. Since the MT-2 cells carry 8 copies of the HTLV-I provirus, the sensitivity of this PCR would be $\geq 8$ copies of viral DNA $/ 1 \times 10^{6}$ cells.

Thirty six subjects were studied, 24 of whom were serologically reactive for HTLV-I/II. Of these 24 subjects only 15 were $\mathrm{Wb}$ confirmed, while the other 9 showed an indeterminate pattern.

Both molecular assays used for the diagnosis of HTLVI and HTLV-II infection allow the amplification of a viral genome sequence that is shared by both retroviruses. In the case of the liquid hybridization PCR used as reference 
technique, the amplified sequence corresponds to a fragment of the pol gene; while in the Nested-PCR the amplified sequence corresponds to a fragment of the tax/rex gene shared by both retroviruses. HTLV-I and HTLV-II are discriminated by the liquid PCR-hybridization by means of specific $\mathrm{P}^{32}$ labeled-probes for HTLV-I and HTLV-II. The products were electrophoresed on polyacrylamide gels and later autoradiographed. In the case of the NestedPCR, the distinction between both retroviruses is made using different restriction enzymes by observing the bands in agarose gels under ultraviolet light.

The samples of the $15 \mathrm{~Wb}$-confirmed subjects were positive by Nested-PCR, 12 of them corresponding to HTLV-I infection and the other 3 corresponding to HTLVII infection. These results show that the Nested-PCR has $100 \%$ sensitivity for both retroviruses. The sensitivity of the PCR-hibridization was lower (67\%) since 10/15 Wbconfirmed subjects were detected by the assay. Moreover, this technique had less sensitivity for the detection of HTLV-II DNA sequences $(1 / 3 ; 33 \%)$ than for the detection of HTLV-I DNA sequences $(9 / 12 ; 75 \%)$.

The samples corresponding to the 12 serologically negative cases for HTLV-I/II were negative by both PCR assays, both molecular assays thus showing $100 \%$ specificity.

Regarding the $9 \mathrm{~Wb}$-indeterminate subjects, both PCR coincided at detecting only one case of HTLV-II infection, the other 8 being negative.

\section{DISCUSSION}

The Nested-PCR showed $100 \%$ sensitivity and specificity for the diagnosis of HTLV-I and HTLV-II infections in Argentina. In contrast, although the liquid PCR-hybridization assay showed $100 \%$ specificity, it showed $67 \%$ sensitivity. It has been reported that in $16 \%$ of HTLV-I infected subjects, the number of PBMCs with the provirus circulating in peripheral blood can be low, ranging from 2 to 68 proviral copies in $1.5 \times 10^{5}$ cells (Matsumoto et al. 1990). On this account, the sensitivity of the technique implemented for the diagnosis of infection by these retroviruses is particularly significant. The Nested-PCR assay we have used proved successful in the detection of HTLV-I with only 8 copies of the provirus in $10^{6}$ cells. The high sensitivity of the Nested-PCR for the detection of HTLV-I/II genomes by amplifying a fragment of the tax/ rex gene and for the viral typing in different parts of the world, have already been described (Matsumoto et al. 1990, Tuke et al. 1992). All this indicates that HTLV-I/II genomes would be highly conserved.

In areas of high endemicity for HTLV-I/II it is very frequent to find subjects serologically reactive by screening techniques but indeterminate by $\mathrm{Wb}$. While in the majority of cases HTLV-I/II sequences are not detected by PCR, there are some cases in which it is possible to amplify by PCR sequences of different HTLV-I/II genes (Saito et al. 1989, Delaporte et al. 1991, Miyata et al. 1995), since some of them become seropositive over time. The data reported suggests the existence of HTLV-I/II infected subjects who are serologically negative. This fact should be taken into account as these retroviruses can be transmitted by blood products and by organ transplants. In relation to this, in this study we found a HTLV-II infection case confirmed by the two PCR assays used, but which presented an indeterminate profile for specific antibodies by $\mathrm{Wb}$. The differences frequently found in the results obtained by different serological assays, emphasizes the difficulty encountered in the serological diagnosis of HTLV-I/II infection and corroborates the need to use a high sensitive and specific molecular assay as a complementary technique in the confirmatory diagnosis of the viral infection. This is in agreement with the report of other authors (Vandamme et al. 1997, Liu et al. 1999, Thorstensson et al. 2002).

We believe that the Nested-PCR protocol described here has some advantages over the reference technique liquid PCR-hybridization in terms of safety, cost and simplicity. Moreover, as a result of the high sensitivity of this technique, we could use simple agarose gel electrophoresis and ethidium bromide staining, thus eliminating the need for radioactives.

In summary, the high sensitivity and specificity of the Nested-PCR showed in this study and its low cost of implementation indicate that this assay could replace the PCRhybridization assay for the molecular diagnosis of HTLVI/II in Argentina. However, other studies should be conducted using a larger number of samples which would be more representative. Finally, the uselfuness of this assay as a tool for the molecular diagnosis of HTLV-I/II infections should be evaluated for its use in other developing countries.

\section{ACKNOWLEDGEMENTS}

To Valeria Mosqueda and Lorena Riquelme for revising the language style of the manuscript.

\section{REFERENCES}

Barun K, Srinivasan A 1989. Multiple primers pairs for the detection of HTLV-I infection by PCR. Nucleic Acids Res 17: 2142 .

Cann A, Chen I 1990. Human T cell leukemia virus types I and II. In BN Fields, Virology, Raven, New York, 1501 pp.

Delaporte E, Monplaisir N, Louwagie J, Peeters M, MartinPrevel Y, Louis JP, Trebucq A, Bedjabaga L, Ossari S, Honore C 1991. Prevalence of HTLV-I and HTLV-II infection in Gabon, Africa: comparison of the serological and PCR results. Int J Cancer 49: 373-376.

Gallego S, Recalde Y, Gastaldello R, Isa M, Nates S, Medeot S 1997. Kinetics study of human retrovirus antigens expression in T lymphocytic cell lines by indirect immunofluorescence assay. Viral Immunol 10: 149-157.

Gastaldello R, Gallego S, Isa M, Maturano E, Sileoni S, Nates $\mathrm{S}$, Medeot S 2001. Immunofluorescence assay reactivity patterns of serum samples presenting indeterminate western blot results for antibodies to HIV-1 and HTLV-I/II in Cordoba, Argentina. Rev Inst Med Trop São Paulo 43: 277282.

Höllsberg P, Hafter D 1993. Pathogenesis of diseases induced by HTLV-I infection. N Engl J Med 328: 1173-1182.

Jacobson S 1996. Cellular immune responses to HTLV-I: immunopathogenic role in HTLV-I associated neurologic disease. J Acq Immune Defic Synd and Hum Retrov 13: 100106.

Kalyanaraman VS, Sarngadharan MG, Robert-Guroff M, Miyoshi I, Golde D, Gallo RC 1982. A new subtype of human T-cell leukemia virus (HTLV-II) associated with a T- 
cell variant of hairy cell leukemia. Science 218: 571-573.

Kwok S, Kellogg D, Ehrlich G, Poiesz B, Bhagavati S, Sminsky JJ 1988. Characterization of the sequence of human T-cell leukaemia virus type 1 from a patient with chronic progressive myelopathy. J Infect Dis 158: 1193-1197.

Lipka J, Young K, Kwok S, Reyes G, Sninsky J, Foung S 1991. Significance of human T-lymphotropic virus type I indeterminate serological findings among healthy individuals. Vox Sang 61: 171-176.

Liu H, Shah M, Stramer SL, Chen W, Weibler BJ, Murphy EL 1999. Sensitivity and specificity of human T-lymphotropic virus (HTLV) types I and II polymerase chain reaction and several serologic assays in screening a population with a high prevalence of HTLV-II. Transfusion 39: 1185-1193.

Matsumoto Ch, Mitsunaga S, Oguchi T, Mitomi Y, Shimada T, Ichikawa A, Watanabe J, Nishioka K 1990. Detection of human T-cell leukemia virus type I (HTLV-I) provirus in an infected cell line and in peripheral mononuclear cells of blood donors by the Nested double polymerase chain reaction method: comparison with HTLV-I antibody tests. $J$ Virol 64: 5290-5294.

Miyata H, Kamahora T, Iha S, Katamine S, Miyamoto T, Hino S 1995. Dependency of antibody titer on provirus load in human T-lymphotropic virus type I carriers: an interpretation for the minor population of seronegative carriers. J Inf Dis 171: 455-460.

Miyoshi I, Kubonishi I, Yoshimoto S, Akagi T, Ohtsuki Y, Shiraishi Y, Nagata K, Hinuma Y 1981. Type C virus particles in a cord T-cell line derived by co-cultivating normal human cord leukocytes and human leukaemic T cells. $\mathrm{Na}$ ture 294:770-771.

Osame M, Usuku K, Izumo S, Ijichi N, Amitani H, Igata A, Matsumoto M, Tara M 1986. HTLV-I associated myelopathy, a new clinical entity. Lancet I: 1031-1032.

Peng C, Huang T, Jeung E, Donaldson C, Vale W, Leung P 1993.
Expression of the type II activin receptor gene in the human placenta. Endocrinology 133: 3046-3049.

Saito S, Ando Y, Furuki K, Kakimoto K, Tanigawa T, Moriyama I, Ichijo M, Nakamura M, Ohtani K, Sugamura K 1989. Detection of HTLV-I genome in seronegative infants born to HTLV-I seropositive mothers by polymerase chain reaction. Jpn J Cancer Res 80: 808-812.

Silva E, Otsuky K, Leite A, Alamy A, Sá-Carvalho D, Paulo Vicente A 2002. HTLV-II infection associated with a chronic neurodegenerative disease: clinical and molecular analysis. J Med Virol 66: 253-257.

Thorstensson R, Albert J, Andersson S 2002. Strategies for diagnosis of HTLV-I and - II. Transfusion 42: 780-791.

Tuke P, Luton P, Garson J 1992. Differential diagnosis of HTLVI and HTLV-II infections by restriction enzyme analysis of 'nested' PCR products. J Virol Methods 40: 163-174.

Uchiyama T, Yodoi J, Sagawa K, Takatsuki K, Uchino H 1977. Adult T-cell leukemia: clinical and hematologic features of 16 cases. Blood 50: 481-492.

Vallejo A, García-Sáiz A 1995. Typing human T-cell lymphotropic virus (HTLV-I and HTLV-II) by nested polymerase chain reaction: application to clinical specimens. J Virol Methods 51: 9-18.

Vandamme AM, Van Laethem K, Liu HF, Van Brussel M, Delaporte E, de Castro Costa CM, Fleischer C, Taylor G, Bertazzoni U, Desmyter J, Goubau P 1997. Use of a generic polymerase chain reaction assay detecting human $\mathrm{T}$ lymphotropic virus (HTLV) types I, II and divergent simian strains in the evaluation of individuals with indeterminate HTLV serology. J Med Virol 52: 1-7.

Zaaijer HL, Cuypers HT, Dudok de Wit C, Lelie PN 1994. Results of 1-year screening of donors in the Netherlands for human T-lymphotropic virus (HTLV) type I: significance of Western blot patterns for confirmation of HTLV infection. Transfusion 34: 877-880. 